\title{
Anmeldelser
}

\section{Den økologiske pagtetik}

Roald E. Kristiansen: $\emptyset$ koteologi, Forlaget Anis, København 1993, 222 sider, 225 kr.

$*$

Det var den biologiske videnskab, der for godt en snes år siden alvorligt gjorde opmarksom på de økologiske faresignaler. Snart fulgte $\emptyset$ konomerne trop bl.a. med fremlæggelse af omfattende rapporter, der pegede på faretruende forhold mellem en eksplosiv befolkningstilvækst, risikoen for udtømming af industrisamfundets mest vitale ressourcer medsamt en konstaterbar nedbrydning af den økologiske balance. Økologien tilkæmpede sig efterhånden en væsentlig plads i den private og offentlige bevidsthed: Det var nu ikke blot den nukleare krig, der kunne gøre det af med os.

Efterhånden begyndte filosofiens repræsentanter at gøre deres synspunkter gældende, hvilket har udvidet og beriget debatten. Begreber som "økologi" og "bæredygtighed" er nu almindelige key-words, der henviser til hvermands viden om en faretruende umiddelbar fremtid. De er ladet med undergangsstemning.

Det må egentlig undre, at teologien har stået underligt svagt i debatten, når nu kristendommen barer kulturen og insisterer på at have svar på eksistentielle grundspørgsmål.

Kristendommen havdes af nogle at vare kommet på mode igen. "Skabskristne" og "de intellektuelle kryber til korset" er tidens overskrifter, som bl.a. peger i retning af et opbrud angående det eksistentielle - en slags besindelse pă de kristne vardier. I nærværende bog antydes frem for alt synspunkter, spørgsmål og fortolkninger, der - såfremt de vinder videre udbredelse - $i$ alt fald vil betyde et opbrud inden for teologien.

Spørgsmålet er, om Roald E. Kristiansens synspunkter kan medføre en debat på bibelsk og kristent grundlag, en debat der ikke blot for de intellektuelle, men også for store dele af de kirkefremmede, afgiver et svar i forhold til de økologiske problemer. Indledningsvis skriver forfatteren, at det primart er hensigten at bidrage til udformningen af den religiøse og videnskabelige vision - eller fremskynde den "tidens fylde", som fører til konkrete nedslag i politiske, sociale, religiøse og videnskabelige handlingsmål: "Hvorvidt det lykkes vil i høj grad afhæenge af, om bogen bliver læst og dens indhold diskuteret." Det er ikke afg $\varnothing$ rende, om man er enig med bogens budskab; det vigtigste er processen, der sættes i gang i og med et kritisk arbejde med bogen.

Roald E. Kristiansen forholder sig mest til protestantisk forståelse og tradition, men refererer også til katolske økoteologer og opfattelser. Modsat romersk katolsk forståelse er der if $\varnothing l g e$ den lutherske intet tilbage af det "naturlige menneske", intet der kan bygges videre på. Det hænger sammen med, at mennesket må se sig selv som helt og aldeles behersket af synden i sit fald. Frelsen fra evig fortabelse opnås alene gennem tro på Guds nåde. Der var og er ikke den mindste rest tilbage. Kristeligt set lagges vagten på åbenbaringen af Kristus; ikke på skabelsen (dette forhold stiller sig anderledes 


\section{Anmeldelser}

ifølge katolsk opfattelse, men berøres ikke). På luthersk grund kan der ikke tales om nogen specifik kristen etik, kultur og politik, idet disse områder er af almenmenneskelig karakter. Når man dertil føjer dogmet om de to svard, som symboliserer hver deres område - det gejstlige (udelukkendeforkyndelse af evangeliet og sakramenteforvaltning) og det verdslige (alt det politiske, kulturelle, m.v.) - som ikke må sammenblandes! - står det klart, at kirken i de protestantiske områder er afskåret fra at bidrage til den $\emptyset$ kologiske debat på afgørende måde. På denne baggrund blæser $\varnothing$ koteologien til storm mod "det herskende" med hensigtserklæringen om verdslige "handlingsmål" på bibelsk grundlag.

Opgaven er i første omgang opgøret med det moderne menneskes dogmer og disses grundlag, dvs. med oplysningstidens rationalistiske livsanskuelse og humanismens ensidige antropocentrisme. Det drejer sig altså om at overvinde denne livsforståelses indsnævring - og konstruere et virkelighedsbillede, hvor biocentrismen erstatter antropocentrismen. Dette skal ske gennem grundlaggelsen af en enhed mellem videnskab, etik, astetik og religion for at nå frem til at anskue tilvarelsen $i$ et helhedsperspektiv. Denne indfaldsvinkel opsum merer Roald E. Kristiansen i fem (syns)punkter: 1) Naturen er organisk og $\emptyset$ kologisk: en dynamisk proces og ikke en ansamling af materielle objekter. 2) Det lavere bør fortolkes i lyset af det højere. 3) Der er ingen absolut modsætning mellem materie og ånd. 4) Vægten skal være biocentrisk: mennesket kan ikke hævde sine rettigheder på andre livsformers bekostning. 5) Hertil kræves en konstruktiv dialog mellem de forskellige fagdiscipliner og forskningstraditioner.

"Det er denne virkelighedsforståelse [...] man må tage alvorligt, hvis kristen tænkning skal have relevans for videnskabelig kosmologi og økologi." I fortsættelsen knytter forfatteren an til Paul Tillichs syn på religionen som dybdedimension i alle livets spørgsmål - hvilket munder ud i endnu et (syns)punkt: 6) "Religionens form må være relevant for videnskabelig kosmologi og en økologisk virkelighedsforståelse."

Kristiansen lagger sig kort sagt i forlangelse af så forskellige folk som Fritjof Capra, Ole Jensen, Ilya Prigogine, Christopher Lasch, Erik Christensen, m.fl. Opgøret med et reduktionistisk videnskabeligt verdensbillede er nu om stunder populær kristen tale...

En anden side af opgøret angår selve den teologiske tradition, først og fremmest luthersk tolkning og forståelse. Som Kristiansen må bryde med det herskende rationelt videnskabelige verdensbillede, må han også nedbryde de vandtatte skodder mellem Luthers verdslige og gejstlige regimente. Herved undermineres (og det er netop intentionen) en af grundpillerne, nemlig den lutherske kaldsetik med den gudvelbehagelige flid og bearbejdning af naturen. Her begynder det måske at brænde alvorligt på for gode protestantiske nordboeres puritanske arbejdsmoral. Kristiansen peger utvivlsomt på noget helt afgørende $\mathrm{i}$ og for den historiske udvikling, når han fremhæver ideologiens indvirkning på teologien. Teologien 


\section{Anmeldelser}

skabes i konfrontation med den kultur, den selv er en del af. Den er nødt til at anvende sin samtids virkelighedsopfattelse i sin teologi og forkyndelse, og samtidig ønsker man at gøre teologien til noget evigt og absolut, som Gud selv er det. Herved forbliver teologien i en relativt uforandret position. "Resultatet er," skriver Kristiansen, "at kirken har beholdt meget af det natur- og verdenssyn, som dannede basis for den industrielle revolution og ekspansionstaenkning fra europaisk imperialisme og kolonialisme og givet denne tænkning en teologisk legitimitet, som kirken i eftertiden har svært ved at give slip på."

Således gør forfatteren op med vasentlige forudsætninger for den herskende opfattelse på de teologiske og kulturelle områder. Først når den kraftige gennemhulning af muren mellem de to lutherske regimenter har fundet sted, er vejen banet for en nytolkning i forhold til en $\emptyset$ kologisk nødvendighed. Dette sker så direkte på grundlag af Bibelen.

Grundbegrebet er pagten, der er indgået mellem Skaberen og hans skabning, mennesket. Der foreligger gensidige forpligtelser om opretholdelse af det skabtes mangfoldighed: altså egentlig en $\emptyset$ kologisk pagt om fallesanliggender mellem Gud og verden, mellem mennesker og naturen. Gud er empatisk til stede og nærværende i verden som den stadigt skabende. Heraf dannes en pagtetik. Denne tolkning sættes i forhold til kristen tro og teologi for at påvise muligheden for dannelsen af en $\emptyset$ kologisk teologi. I lyset af pagten (som en $\emptyset$ kologisk pagt) nytolkes begreberne synd, nåde og frelse: Synd i religiøs forstand er "ødelæggelse af livets helhed". Frelsen er genrejsning af livets helhed - den "nye skabelse", der overvinder de $\varnothing$ delæggende krafter og bygger Guds rige, hvor synd og død ikke længere har nogen magt. Derved er skabelsens virkelighed det "sted", hvor frelsen skal virkeliggøres.

Økoteologi er simpelthen et menneskeligt fors $\varnothing \mathrm{g}$ på at konkretisere, hvad frelsesbudskabet indebarer over for naturens verden. Frelsen som tro på Kristus som den døde og opstandne spiller ingen rolle. Det er forholdet til det skabtes helhed, der alene er afgørende. Ansvaret herfor er menneskets. Dette er jo selvsagt en afgørende fravigelse fra kristendommen. Kristus er der ikke.

En teologi for naturen må naturligvis besinde sig på den moderne videnskab. Dette sker gennem procesteologien, hvor det "at blive til" er en primærkategori, og hvor selve relationen mellem det tilblivende har prioritet frem for de eksisterende elementer selv. Skabelse i procesteologisk forstand forstås som vekselvirkning mellem disse to forhold. Det vil sige at det i kristendommen centrale - frelsen - sker i selve processen. Skabelse er frelse.

I et af sluttende kapitel drager Kristiansen sin endelige konklusion. Han gør galdende, at $\varnothing$ koteologien skal hvile på procesteologisk grundlag. Den skal vare forankret i tre etiske grundvardier. 1) Alt som eksisterer er til gennem et netværk af relationer, som konstituerer deres eksistens. 2) Vardier som integration, helhed og harmoni er grundlæggende for alt liv og må søges fremmet på alle planer. 3) Den procesteologiske for- 


\section{Anmeldelser}

ståelse af "erfaring" som en måde at forholde sig aktivt til sine omgivelser på gør at alle relationer og forhold, man går ind $\mathrm{i}$, må være præget af viljen til medfølelse og indsigt. Det betyder blandt andet anerkendelsen af alle organismers egenværdi og følgelig ret til eksistens og udfoldelse på egne præmisser.

Det er karakteristisk for bogen, at dens forfatter foretager sine analyser og fremsatter sine argumenter $i$ et vederhæftigt, afdæmpet og letlæst sprog - samtidig med at han rundhåndet angiver skriftstederne. Det er en yderligere kvalitet, at bogen er forsynet med gode oplysende noter og et ret omfattende personregister. Dette virker betryggende, for det er et stort og "farligt" ærinde, Kristiansen er ude i.

Bogen bør læses af alle og gøres til genstand for et grundigt studium. Det afg $\varnothing$ rende er jo som nævnt ikke, hvorvidt man er enig med forfatteren.

Lars Krause Fisker "...heller ikke hen, hvor en snadrende Bak over Marken trasker vak"

Søren Kierkegaard: Dagbøger i udvalg 1834-1846, Danske klassikere, Det danske

Sprog- og Litteraturselskab, Borgen 1993.

Tekstudgivelse, efterskrift og noter af Jørgen Dehs under medvirken af Niels Jørgen Cappelørn.

Siden Georg Lukacs i Theorie des Romans brugte følgende tre ord om de foreteelser, man fandt i grøftekanten af historiens landevej: diskret, heterogen og kontingent - siden da har disse foreteelser udgjort det afg $\emptyset$ rende problem for den moderne tanke; eller forsøget på at tænke moderne.

Tematisk er emnerne i Kierkegaards dagbøger da også at ligne med et pulterkammer. Mixed up confusion. Der er læst en masse Hegel, og Hegels måde at orientere sig i pulterkammeret på har sat sit dybe spor på tankemåden. Men vejen ud igen, som Hegel trods alt sluttede med, er for alvor spærret og romantikkens forsoninger blevet umulige. Hvis Hegel må kaldes for en filosofisk senromantiker, så er Kierkegaard den filosofiske efterromantiker. Idet betegnelsen efterromantik overføres fra litteraturhistorien på filosofiens historie.

Opgøret med romantikken ser Kierkegaard i dagbøgerne - foregribende Enten-eller, 1 som en historisk reaktualisering af momenter fra antikkens tragikbestemmelse lige midt i hjertekulen af romantikernes tragedie- 